\section{Absence of SLC22A12/URAT1 Gene Mutations in Patients with Primary Gout}

To the Editor:

In most patients with primary gout, hyperuricemia has been related to a decreased urinary uric acid excretion, but the specific gene abnormalities that may cause an impaired tubular transport of urate are unknown. The first urate transporter described was $S L C 22 A 12 / U R A T 1^{1}$. Mutations in the SLC22A12/URAT1 gene have been associated to primary renal hypouricemia type I (OMIN 220150) in several populations $s^{1,2,3,4,5}$, although some ethnic differences may explain the lack of association between this gene and primary renal hypouricemia in other populations such as Greek whites ${ }^{6}$. Because this transporter reabsorbs urate from the renal tubule, loss of function mutations may cause renal urate wasting and hypouricemia. However, it has been reported that among 69 Mexican patients with primary gout, 16 (23\%) showed 6 different SLC22A12/URAT1 mutations ${ }^{7}$. Could these mutations explain hyperuricemia due to impaired renal uric acid excretion? Although none of these mutations was segregated in the 240 chromosomes of healthy individuals ${ }^{7}$, no study has confirmed or refuted SLC22A12/URAT1 mutations in patients with gout, and it is uncertain whether an enhanced tubular reabsorption of urate may cause hyperuricemia. Notably, one of these mutations has also been associated with primary renal hypouricemia type $\mathrm{I}^{7}$.

In an extensive series of white patients with primary gout, we have determined whether the previously reported SLC22A12/URAT1 gene mutations in Mexican patients with gout, or other mutations in this gene, could explain their increased serum urate concentrations.

Seventy-seven patients with primary gout according to Wallace, et $a l^{8}$ criteria and who had had at least 2 acute gouty arthritis episodes were studied at the metabolic and vascular unit of La Paz University Hospital, Madrid, Spain. All studies were conducted according to the Declaration of Helsinki, and were approved by the Institutional Research and Ethics Review Committees of La Paz University Hospital. Among the 77 patients with gout, 73 were men $(95 \%)$. Their mean age $( \pm$ SD) was $59.8 \pm 9.1$ years. Mean serum urate concentration was $8.2 \pm 1.5 \mathrm{mg} / \mathrm{dl}$ and 24 -h uric acid excretion was $455 \pm 111 \mathrm{mg} / 24 \mathrm{~h} / 1.73 \mathrm{~m}^{2}$. All patients exhibited a decreased urinary uric acid excretion rate, according to their increased serum urate levels ${ }^{9}$.

RNA-free genomic DNA samples from patients with gout were isolated from whole blood, and the 10 exons of the human SLC22A12/URAT1 gene were amplified by polymerase chain reaction with the gene's flanking intron sequences. Strands (forward and reverse) of the amplified DNA fragments were sequenced in an ABI Prism 377 DNA Sequencer (Applied Biosystems, Foster City, CA, USA).

Both forward and reverse sequences were successful and consistent. Genetic analysis detected no mutations in the SLC22A12/URAT1 gene, except for the previously reported silent polymorphisms rs 3825016, 11231825, 1630320, 7932775, and the intronic polymorphism rs 79866595. In this regard, in recent years serum uric acid has been associated with several single-nucleotide polymorphisms (SNP) of different genes, mainly by genome-wide association studies (GWAS). SNP in SLC22A12/URAT1 were first associated with hyperuricemia in white, Japanese, and Italian cohorts. Association was replicated in other GWAS in population-based cohorts ${ }^{10}$, although this contributes only modestly to explaining variability in serum urate.

The absence of SLC22A12/URAT1 coding sequence mutations in our Spanish patients with gout can best be interpreted to mean that their decreased uricosuria and hyperuricemia cannot be attributed to an abnormality in this transporter. However, a mutation in the noncoding sequence of this gene, or in other different genes, that may lead to increased amounts of URAT1 protein cannot be ruled out. A disturbance in other tubular urate transporters, such as ABCG2, which secretes urate into the tubular lumen, may contribute to reduce uric acid excretion and increase serum urate concentrations. We wonder whether the previously reported base substitutions in Mexican patients ${ }^{7}$ could be related to silent polymorphisms instead of gain-of-function mutations.

ROSA J. TORRES, MD, PhD, Clinical Biochemistry Division; EUGENIO DE MIGUEL, MD, PhD, Rheumatology Division; REBECA BAILEN, Medical Student; JUAN G. PUIG, MD, PhD, Internal Medicine Division, Metabolic Vascular Unit, IdiPAZ, La Paz University Hospital, Madrid, Spain. Address correspondence to Dr. R.J. Torres, Servicio de Bioquímica, Edificio Laboratorio, Hospital Universitario La Paz, Paseo de la Castellana 261, 28046 Madrid, Spain.

E-mail: rtorres.hulp@salud.madrid.org

Supported by a grant from Fondo de Investigaciones Sanitarias (Healthcare Research Fund; FIS 08/0009).

\section{REFERENCES}

1. Enomoto A, Kimura H, Chairoungdua A, Shigeta Y, Jutabha P, Cha $\mathrm{SH}$, et al. Molecular identification of a renal urate anion exchanger that regulates blood urate levels. Nature 2002;417:447-52.

2. Ichida K, Hosoyamada M, Hisatome I, Enomoto A, Hikita M, Endou $\mathrm{H}$, et al. Clinical and molecular analysis of patients with renal hypouricemia in Japan - Influence of URAT1 gene on urinary urate excretion. J Am Soc Nephrol 2004;15:164-73.

3. Cheong HI, Kang JH, Lee JH, Ha IS, Kim S, Komoda F, et al. Mutational analysis of idiopathic renal hypouricemia in Korea. Pediatr Nephrol 2005;20:886-90.

4. Dinour D, Bahn A, Ganon L, Ron R, Geifman-Holtzman O, Knecht A, et al. URAT1 mutations cause renal hypouricemia type 1 in Iraqi Jews. Nephrol Dial Transplant 2011;26:2175-81.

5. Sebesta I, Stiburkova B, Bartl J, Ichida K, Hosoyamada M, Taylor $\mathrm{J}$, et al. Diagnostic tests for primary renal hypouricemia. Nucleosides Nucleotides Nucleic Acids 2011;30:1112-6.

6. Tzovaras V, Chatzikyriakidou A, Bairaktari E, Liberopoulos EN, Georgiou I, Elisaf M. Absence of SLC22A12 gene mutations in Greek Caucasian patients with primary renal hypouricaemia. Scand J Clin Lab Invest 2007;67:589-95.

7. Vázquez-Mellado J, Jiménez-Vaca AL, Cuevas-Covarrubias S, Alvarado-Romano V, Pozo-Molina G, Burgos-Vargas R. Molecular analysis of the SLC22A12 (URAT1) gene in patients with primary gout. Rheumatology 2007;46:215-9.

8. Wallace SL, Robinson H, Masi AT, Decker JL, McCarty DJ, Yü T-F. Preliminary criteria for the classification of the acute arthritis of primary gout. Arthritis Rheum 1977;20:895-900.

9. Puig JG, Torres RJ, de Miguel E, Sánchez A, Bailén R, Banegas JR. Uric acid excretion in healthy subjects: A nomogram to assess the mechanisms underlying purine metabolic disorders. Metabolism 2012;61:512-8.

10. Kolz M, Johnson T, Sanna S, Teumer A, Vitart V, Perola M, et al. Meta-analysis of 28,141 individuals identifies common variants within five new loci that influence uric acid concentrations. PLoS Genet 2009;5:e1000504.

J Rheumatol 2012;39:9; doi:10.3899/jrheum.120451 